\title{
Use of Temperature-sensitive Mutants to Study Gene Expression of Two Closely Linked Sporulation Loci in Bacillus subtilis
}

\author{
By IAIN L. LAMONT AND JOEL MANDELSTAM* \\ Microbiology Unit, Department of Biochemistry, University of Oxford, Oxford OX13QU, UK
}

(Received 16 November 1983 ; revised 22 December 1983)

\begin{abstract}
The spoOB and spoIVF loci are contiguous on the chromosome of Bacillus subtilis, so that genes in these loci may be parts of a single polycistronic operon. Temperature-sensitive strains having mutations in these loci were isolated, and temperature-shift experiments were carried out to investigate expression of the genes. The temperature-sensitive periods of spoOB mutants extended from the beginning of sporulation until the end of the stage II. The temperaturesensitive periods of spoIVF strains were during stage IV of sporulation. Therefore, although the spoOB and spoIVF loci are contiguous on the chromosome it is unlikely that genes in them are parts of a single polycistronic operon.
\end{abstract}

\section{INTRODUCTION}

In an accompanying paper (Lamont \& Mandelstam, 1984), we discussed the possibility that sporulation genes in Bacillus subtilis are in polycistronic operons, and that mutations in different genes in a single operon might give blocks at different stages of sporulation. The $s p o O B$ and spoIVF sporulation loci, which lie near to phe $A$ on the chromosome, are almost certainly contiguous (Hoch et al., 1978; see also below). They could therefore contain genes which are parts of the same polycistronic operon, as suggested by Hoch et al. (1978). It is known that the spoOB locus is expressed during vegetative growth and the early stages of sporulation (Brehm et al., 1975; Hirochika et al., 1981), but work on the expression of the spoIVF locus has not been reported.

The use of temperature-sensitive mutants to determine the times at which the products of sporulation genes are involved in the process was investigated by Young (1976). We have applied the method to temperature-sensitive strains with mutations in the spoOB and spoIVF loci. Our results show that while the $s p o O B$ gene is expressed during vegetative growth and the earliest stages of sporulation, the spoIVF locus appears to be expressed much later. It is therefore unlikely that genes in these loci are parts of a single polycistronic operon.

\section{METHODS}

Organisms. The strains used are listed in Table 1. Strains 580, 581 and 587 were identified as being temperaturesensitive sporulation mutants following directed mutagenesis (Errington \& Mandelstam, 1983) of the phe A region of the chromosome, as described in the accompanying paper (Lamont \& Mandelstam, 1984).

Growth and sporulation. This was done as described in the accompanying paper (Lamont \& Mandelstam, 1984). The temperatures at which cultures were incubated are given in the Figure legends.

Alkaline phosphatase. Samples were removed from cultures at $t_{5}$ and were assayed for the presence of alkaline phosphatase by the method of Glenn \& Mandelstam (1971).

Measurement of heat-resistance. This was done as described by Lamont \& Mandelstam (1984).

Temperature-shift experiments. For 'shift-up' experiments, cultures $(70-80 \mathrm{ml})$ were incubated at $34^{\circ} \mathrm{C}$. Portions (3-5 ml) were removed at regular intervals, put into $100 \mathrm{ml}$ flasks, and incubated at $42^{\circ} \mathrm{C}$. At least $15 \mathrm{~min}$ after the

Abbreviation: RI, recombination index. 
Table 1. Organisms

\begin{tabular}{|c|c|c|c|}
\hline Strain & Genotype & $\begin{array}{c}\text { Sporulation } \\
\text { phenotype }\end{array}$ & Source \\
\hline 168 & $\operatorname{trp} C 2$ & $\mathrm{Spo}^{+}$ & Laboratory stock \\
\hline $\begin{array}{l}\text { MB68 } \\
\text { MB68.1 } \\
\text { MB79 }\end{array}$ & $\begin{array}{l}\text { pheA12 lys-1 } \\
\text { lys-1 } \\
\text { pheA12 metC3 }\end{array}$ & $\begin{array}{l}\mathrm{Spo}^{+} \\
\mathrm{Spo}^{+} \\
\mathrm{Spo}^{+}\end{array}$ & $\begin{array}{l}\text { Laboratory stock } \\
\text { Laboratory stock } \\
\text { Laboratory stock }\end{array}$ \\
\hline $\begin{array}{l}580 \\
581\end{array}$ & $\begin{array}{l}\text { spo0B580 lys-I } \\
\text { spo0B581 lys-1 }\end{array}$ & $\begin{array}{l}\text { Spo } \\
\text { Spo }^{\text {ts }}\end{array}$ & $\begin{array}{l}\text { Directed mutagenesis of MB68 } \\
\text { Directed mutagenesis of MB68 }\end{array}$ \\
\hline 587 & spoIVF587 lys-1 & $\mathrm{Spo}^{\text {ts }}$ & Directed mutagenesis of MB68 \\
\hline $\begin{array}{l}181 \\
181.3 \\
181.4\end{array}$ & $\begin{array}{l}\text { spoIVFI81 trpC2 } \\
\text { spoIVF181 lys-1 } \\
\text { spoIVF181 metC3 }\end{array}$ & $\begin{array}{l}\mathrm{Spo}^{\text {ts }} \\
\mathrm{Spo}^{\text {ts }} \\
\mathrm{Spo}^{\text {ts }}\end{array}$ & $\begin{array}{l}\text { Laboratory stock } \\
\mathrm{Phe}^{+} \mathrm{Spo}^{\text {ts }} \text { transformant of strain MB68, donor } 181 \\
\mathrm{Phe}^{+} \mathrm{Spo}^{\text {ts }} \text { transformant of strain MB79, donor } 181\end{array}$ \\
\hline $\begin{array}{l}132 \\
132.3 \\
488.1 \\
488.3\end{array}$ & $\begin{array}{l}\text { spoIVF132 trpC2 } \\
\text { spoIVF132 lys-1 } \\
\text { spoOB } 136 \text { lys-1 } \\
\text { spo0B } 136 \text { purA16 }\end{array}$ & $\begin{array}{l}\text { Spo- }^{-} \\
\text {Spo }^{-} \\
\text {Spo- } \\
\text { Spo- }\end{array}$ & $\begin{array}{l}\text { Laboratory stock } \\
\text { Laboratory stock } \\
\text { Laboratory stock } \\
\text { Laboratory stock }\end{array}$ \\
\hline
\end{tabular}

last sample had been taken, the sample cultures were transferred to $37^{\circ} \mathrm{C}$ and incubated overnight, to allow the release of spores from cells. The numbers of heat-resistant spores present in each culture were then measured.

For 'shift-down' experiments, the same method was used except that the large (70-80 ml) cultures were incubated at $42^{\circ} \mathrm{C}$, and the samples $(3-5 \mathrm{ml})$ were incubated at $34^{\circ} \mathrm{C}$. The samples were incubated at $30^{\circ} \mathrm{C}$ overnight. Cells in samples which were incubated at $34^{\circ} \mathrm{C}$ before $t_{0}$ (i.e. while growing in hydrolysed casein medium) were transferred to resuspension medium when the cultures reached appropriate cell densities.

Calculation of the temperature-sensitive periods of mutants. The temperature-sensitive periods of the mutants were calculated using the method of Esposito et al. (1970), as described by Young (1976). If $f_{\mathrm{i}}$ is the fraction of total sporulation time when the temperature-sensitive period is initiated, and $f_{\mathrm{e}}$ the time when it ends, then $f_{\mathrm{i}}=t_{\mathrm{i}} \sigma / t_{\mathrm{a}}$ and $f_{\mathrm{e}}=t_{\mathrm{e}} / t_{\mathrm{a}}$, where $t_{\mathrm{i}}$ is the time in hours after resuspension at $42{ }^{\circ} \mathrm{C}$ at which a 'shift-down' reduces the number of heat-resistant colony-forming units by $10 \%, t_{\mathrm{e}}$ is the time at which 'shift-up' results in the formation of $10 \%$ of the maximum number of heat-resistant colony-forming units and $t_{\mathrm{a}}$ (the 'total sporulation time') is the time at which continuous incubation of the mutant at the permissive temperature results in $10 \%$ of the maximum number of heat-resistant c.f.u. $\sigma$ is the ratio for the wild-type of total sporulation time at the permissive temperature to that at the restrictive temperature. When calculating $f_{i}, \sigma$ compensates for the fact that sporulation proceeds more slowly at the permissive temperature than at the restrictive temperature. The temperature-sensitive period of each mutant is from $f_{\mathrm{i}}$ to $f_{\mathrm{e}}$. In calculating $f_{\mathrm{i}}$ and $f_{\mathrm{e}}$ in this way, it is assumed than any particular stage takes the same amount of time in all strains at each incubation temperature.

Transformation. DNA was prepared by the method of Marmur (1961) or by the method of Ward \& Zahler (1973). Transformation was carried out, and recombination indices (RI) were calculated, as described in the accompanying paper (Lamont \& Mandelstam, 1984). An RI of $0 \cdot 1$, or less, indicates that two mutations probably lie in the same or contiguous genes (Carlton, 1966), and an RI of about $\mathbf{0 . 3}$ or less indicates that two mutations may lie in different genes in the same operon (Piggot \& Coote, 1976).

\section{RESULTS}

\section{Isolation and characterization of temperature-sensitive mutants}

Strains 580, 581 and 587 were isolated following directed mutagenesis of the phe $A$ region of the $B$. subtilis chromosome. Strains 580 and 581 formed half-length cells during incubation in sporulation medium, a phenotype which is associated with certain spo0 mutations (Dunn et al., 1976), and failed to form alkaline phosphatase (a stage II event). Values for the cotransformation of these mutations with phe $A$ were $74 \%(209 / 281)$ for $s p o-580$ and $78 \%(626 / 801)$ for $s p o-581$. These are in agreement with previously reported values for mutations in the $s p o 0 B$ locus (Hoch \& Mathews, 1973). The RI values between the newly-identified mutations and a mutation which is known to lie in the $s p o 0 B$ locus are shown in Table 2 . The values obtained were less than $0 \cdot 1$, and so they indicate that mutations spo-580 and spo-581 are likely to lie in the spoOB locus.

Strain 181 was isolated by Dr D. Grant (unpublished results) and the spo mutation which it carries was found to be $93 \%$ linked to $p$ he $A$ by PBS1-mediated transduction. Strains 181 and 587 
Table 2. Recombination indices between newly identified spo mutations and known spo mutations

Strains carrying the newly identified spo mutations were transformed with saturating amounts of DNA (2-8 $\mu \mathrm{g} \mathrm{ml}^{-1}$ ) prepared by the method of Marmur (1961) from (i) strain $168 \operatorname{trpC2}$ and (ii) strain 488.3 spoOB 136 purA16 or strain 132 spoIVF trpC2. [Mutation spo-136 was assigned to the $s p o 0 B$ locus by Hoch \& Mathews (1973); mutation spo-132 was assigned to the spoIVF locus by Coote (1972b).] Prototrophic transformants were selected in all crosses. The proportion of $\mathrm{Spo}^{+}$recombinants arising from each cross was found after 3-4 dincubation at $37^{\circ} \mathrm{C}$. Similar crosses were carried out to determine the RI between spoOB136 and spoIVF132. RI values were calculated by the method of Coote (1972b).

$\begin{array}{lcc}\text { Recipient strain } & \overbrace{488.3(\text { spoOB) }} & 132(\text { spoIVF) } \\ 580 \text { spo-580 lys-1 } & 0.08 & 0.24 \\ 581 \text { spo-581 lys }-1 & 0.03 & 0.23 \\ 587 \text { spo-587 lys-1 } & 0.16 & 0.05 \\ 181.4 \text { spo-18I metC3 } & 0.30 & 0.20 \\ 132.3 \text { spoIVF132 lys-1 } & 0.18 & \\ 488.1 \text { spoOB } 136 \text { lys }-1 & & 0.21\end{array}$

Table 3. Effect of temperature on sporulation of Spo ${ }^{\text {ts }}$ strains

\begin{abstract}
Strains were induced to sporulate at $34^{\circ} \mathrm{C}$ and at $42^{\circ} \mathrm{C}$ by transfer to resuspension medium following growth in casein hydrolysate medium. Samples of each culture were heated at $80^{\circ} \mathrm{C}$ for 15 min after at least $6 \mathrm{~h}$ incubation at $42^{\circ} \mathrm{C}$ or $12 \mathrm{~h}$ at $34^{\circ} \mathrm{C}$. They were then diluted and plated onto nutrient agar. The numbers of heat-resistant c.f.u. $\mathrm{ml}^{-1}$ were found after overnight incubation at $37^{\circ} \mathrm{C}$. The values given are the averages of at least three experiments at each temperature except for strains 181.3 and 181.4 (two experiments). The complete genotypes of the strains are given in Table 1.
\end{abstract}

$\begin{array}{lccc}\text { Strain } & \begin{array}{c}\text { Heat-resistant } \\ \text { c.f.u. ml }{ }^{-1} \text { after } \\ \text { incubation at } 34^{\circ} \mathrm{C}(a)\end{array} & \begin{array}{c}\text { Heat-resistant } \\ \text { c.f.u. ml }{ }^{-1} \text { after } \\ \text { incubation at } 42^{\circ} \mathrm{C}(b)\end{array} & \text { Ratio b/a } \\ \text { MB68.1 } & 1.8 \times 10^{8} & 1.4 \times 10^{8} & 0.78 \\ 580 \text { spo0B } & 1.7 \times 10^{8} & 2.0 \times 10^{6} & 0.012 \\ 581 \text { spo0B } & 6.7 \times 10^{7} & 5.3 \times 10^{5} & 0.008 \\ 587 \text { spoIVF } & 2.9 \times 10^{8} & 1.6 \times 10^{6} & 0.005 \\ 181 \text { spoIVF } & 1.0 \times 10^{8} & 3.0 \times 10^{6} & 0.030 \\ 181.3 \text { spoIVF } & 1.1 \times 10^{7} & 3.5 \times 10^{4} & 0.003 \\ 181.4 \text { spoIVF } & 7.0 \times 10^{7} & 3.5 \times 10^{4} & 0.048\end{array}$

formed wild-type amounts of alkaline phosphatase during sporulation and formed phase-grey prespores, as detected by phase-contrast microscopy. No further prespore development took place in cells of these strains. This phenotype is the same as that associated with mutations in the spoIVF locus (Coote, 1972a). Values for the co-transformation of these mutations with phe $A$ were $58 \%(771 / 1319)$ for spo-181 and $70 \%(98 / 142)$ for spo-587. These are in agreement with previously reported values for mutations in the spoIVF locus (Hranueli et al., 1974). The RI values between the newly identified mutations and a mutation which lies in the spoIVF locus are shown in Table 2. They indicate that the new mutations are in the same gene as mutation spoIVF132, or in the gene adjacent to it.

On the basis of the phenotypic and genetic criteria described above, mutations spo-580 and spo-581 were assigned to the spoOB locus, and mutations spo-587 and spo-181 to the spoIVF locus.

RI values between mutations in the $s p o O B$ and spoIVF loci range between $0 \cdot 16$ and $0 \cdot 30$ (Table 2). These values indicate that the two loci may well be contiguous and could be parts of a single operon (Piggot \& Coote, 1976), as has been suggested previously (Hoch et al., 1978).

\title{
Sporulation of mutants during incubation at $34{ }^{\circ} \mathrm{C}$ and at $42{ }^{\circ} \mathrm{C}$
}

The incidences of formation of heat-resistant spores by different strains during incubation at $34{ }^{\circ} \mathrm{C}$ and at $42{ }^{\circ} \mathrm{C}$ are shown in Table 3 . The total sporulation times of the temperature-sensitive strains at $34^{\circ} \mathrm{C}$, and of the $\mathrm{Spo}^{+}$strain MB68.1 lys-1 at $34{ }^{\circ} \mathrm{C}$ and at $42{ }^{\circ} \mathrm{C}$, were found by 


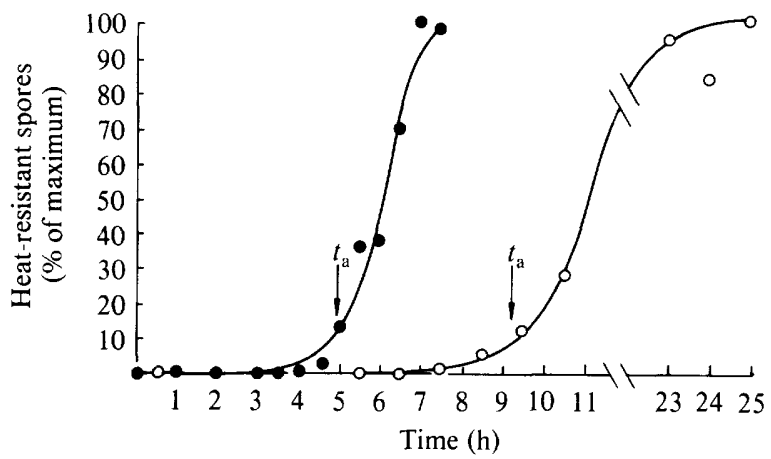

Fig. 1. Total sporulation time of strain MB68.1 Spo ${ }^{+}$incubated at $34{ }^{\circ} \mathrm{C}$ and at $42^{\circ} \mathrm{C}$. A culture of strain MB68.1 lys- $1 \mathrm{Spo}^{+}$was grown in casein hydrolysate medium incubated at $34^{\circ} \mathrm{C}$ or at $42^{\circ} \mathrm{C}$ and was then transferred to sporulation medium. Incubation was continued at the same temperature. Samples were taken at intervals and were assayed for the presence of heat-resistant spores. The maximum values were $1.76 \times 10^{8} \mathrm{ml}^{-1}\left(34^{\circ} \mathrm{C}\right)$ and $1.17 \times 10^{8} \mathrm{ml}^{-1}\left(42^{\circ} \mathrm{C}\right) . t_{\mathrm{a}}$ denotes the total sporulation time and is taken as the point at which $10 \%$ of the maximum number of heat-resistant spores were present. At $34^{\circ} \mathrm{C}(\mathrm{O}) t_{\mathrm{a}}$ was $9.25 \mathrm{~h}$ and at $42^{\circ} \mathrm{C}(O) t_{\mathrm{a}}$ was $5.0 \mathrm{~h} . \sigma$, the ratio of the total sporulation time of strain $\mathrm{MB} 68.1$ at $34^{\circ} \mathrm{C}$ to that at $42^{\circ} \mathrm{C}$, was $1 \cdot 75(9 \cdot 25 / 5 \cdot 0)$.
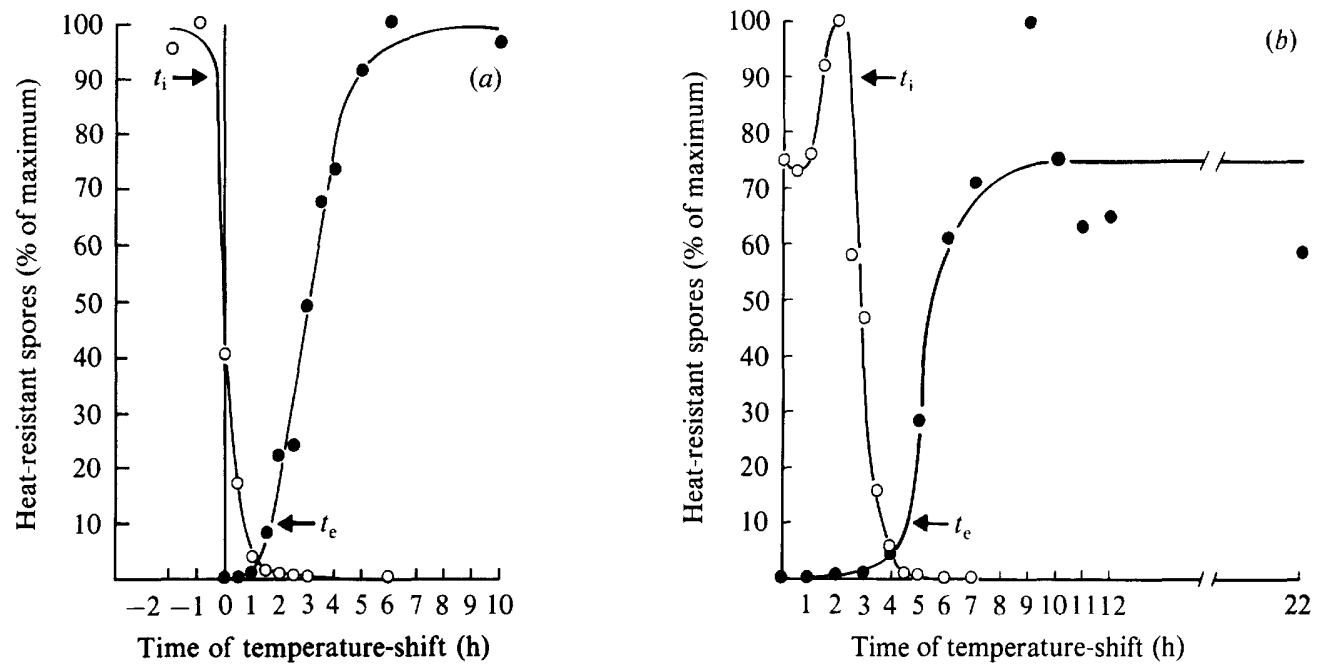

Fig. 2. Effects of temperature-shift on sporulation of strains 580 and 587. (a) 580, (b) 587. O, 'Shift down': cultures growing at $42^{\circ} \mathrm{C}$ in casein hydrolysate medium were transferred to sporulation medium and were incubated at $42^{\circ} \mathrm{C}$. Samples were removed at intervals and incubated at $34^{\circ} \mathrm{C}$. Samples which were moved to $34^{\circ} \mathrm{C}$ while growing in casein hydrolysate medium were transferred to sporulation medium when they reached the appropriate cell density, and incubated at $34^{\circ} \mathrm{C}$. The numbers of heatresistant spores ultimately formed in each sample were measured. The maximum values were $2.20 \times$ $10^{8} \mathrm{ml}^{-1}(580)$ and $2.17 \times 10^{8} \mathrm{ml}^{-1}(587) . t_{\mathrm{i}}$ is the time at which $90 \%$ of the maximum number of heatresistant spores were formed. 'Shift up': cultures growing at $34^{\circ} \mathrm{C}$ in casein hydrolysate medium were transferred to sporulation medium and were incubated at $34^{\circ} \mathrm{C}$. Samples were removed at intervals and incubated at $42^{\circ} \mathrm{C}$. The numbers of heat-resistant spores ultimately formed in each sample were measured. The maximum values were $1.98 \times 10^{8} \mathrm{ml}^{-1}(580)$ and $4.00 \times 10^{8} \mathrm{ml}^{-1}(587) . t_{\mathrm{e}}$ is the time at which $10 \%$ of the maximum number of heat-resistant spores were formed. 


\begin{tabular}{lllllllll} 
Vegetative \\
growth & I & Il & III & IV & V & Vl \\
\hline
\end{tabular}

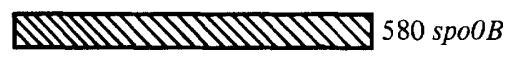

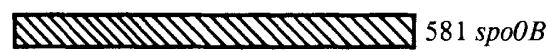

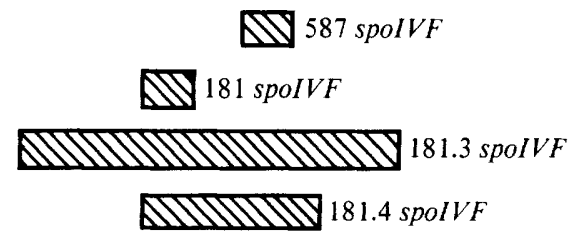

Fig. 3. Temperature-sensitive periods of $s p o O B$ and $s p o I V F$ strains. The temperature-sensitive periods of the strains used are represented by areas of shading. They were found by calculating the values of $f_{i}$ (beginning of the temperature-sensitive period) and $f_{\mathrm{e}}$ (end of the temperature-sensitive period) (see Methods and Table 4).

\section{Table 4. Determination of the temperature-sensitive periods of sporulation mutants}

Graphs illustrating the derivation of the parameters $t_{\mathrm{a}}$ (total sporulation time), $t_{\mathrm{i}}$ (inhibition time) and $t_{\mathrm{e}}$ (escape time) are shown in Figs 1 and 2 . These parameters were found for each strain. The parameters $f_{\mathrm{i}}$ and $f_{\mathrm{e}}$, which represent the start and the end of the temperature-sensitive periods, were then calculated using the method of Esposito et al. (1970), as described in Methods, and with a value for $\sigma$ of 1.75 (see text and Fig. 1). All values represent the average values of two or three experiments. Values of $t_{\mathrm{a}}, t_{\mathrm{i}}$ and $t_{\mathrm{e}}$ are expressed in $\mathrm{h}$.

\begin{tabular}{lccccc}
\multicolumn{1}{c}{ Strain } & $t_{\mathrm{a}}$ & $t_{\mathrm{i}}$ & \multicolumn{1}{c}{$t_{\mathrm{e}}$} & \multicolumn{1}{c}{$f_{\mathrm{i}}$} & $f_{\mathrm{e}}$ \\
580 spoOB lys-1 & 7.0 & -0.5 & 1.75 & -0.07 & 0.25 \\
581 spo0B lys-1 & 7.0 & -0.5 & 2.0 & -0.07 & 0.29 \\
587 spoIVF lys-1 & 6.75 & 2.25 & 4.25 & 0.58 & 0.63 \\
181 spoIVF trpC2 & 7.25 & 2.0 & 3.75 & 0.48 & 0.53 \\
181.3 spoIVF lys-1 & 8.5 & 1.75 & 6.5 & 0.36 & 0.76 \\
181.4 spoIVF metC3 & 7.25 & 2.0 & 4.75 & 0.48 & 0.66
\end{tabular}

incubating cultures at the appropriate temperatures in resuspension medium and then taking samples at intervals and testing them for the numbers of heat-resistant spores which were present. The results of experiments with strain MB68.1, and the derivation of the total sporulation time $\left(t_{\mathrm{a}}\right)$, are shown in Fig. 1 . The total sporulation times of all the strains, found from experiments similar to those shown in Fig. 1, are listed in Table 4. $\sigma$, the ratio of the total sporulation time of strain MB68.1 at $34{ }^{\circ} \mathrm{C}$ to that at $42^{\circ} \mathrm{C}$, was 1.75 . This is similar to the value of 1.70 obtained by Young (1976).

\section{Temperature-sensitive periods of spoOB and spoIVF strains}

The temperature-sensitive periods of the mutants were determined by 'shift-up' and 'shiftdown' experiments. The results of experiments with strains 580 and 587 are shown in Fig. 2. The results obtained with all of the strains used are given in Table 4.

The parameters $f_{\mathrm{i}}$ and $f_{\mathrm{e}}$ which represent, respectively, the beginning and end of the temperature-sensitive periods of the different strains. were calculated using the formula of Esposito et al. (1970), as described in Methods. The values of $f_{\mathrm{i}}$ and $f_{\mathrm{e}}$ obtained with each strain are given in Table 4, and the temperature-sensitive periods are represented in Fig. 3.

\section{DISCUSSION}

Strains $580 s p o 0 B, 581 s p o 0 B, 181$ spoIVF and 587 spoIVF are temperature-sensitive for sporulation. We have used temperature-shift experiments to determine the temperaturesensitive periods of these strains. The results are shown diagrammatically in Fig. 3. 
Strains 580 and 581 had similar temperature-sensitive periods. Any other finding would have been surprising since the $s p o 0 B$ locus contains only one complementation group (Hirochika et $a l ., 1981$; Ferrari et al., 1982). The frequencies of sporulation of these strains were influenced by the incubation temperature during vegetative growth as well as during sporulation (Fig. $2 a$ and Table 4). This shows that the $\operatorname{spoOB}$ gene was expressed during vegetative growth, as has been reported previously (Brehm et al., 1975; Hirochika et al., 1981). The temperature-sensitive periods of strains 580 and 581 extended to the end of stage II. Sato et al. (quoted in Hirochika et al., 1981) stated that the temperature-sensitive period of a strain carrying a different spo0B mutation ends at $t_{1.5}$, which is a similar result if the incubation temperature used by those workers was $37^{\circ} \mathrm{C}$.

The temperature-sensitive periods of the spoIVF strains did not begin until after stage III (Fig. 3). The temperature-sensitive periods of strains 587, 181 and 181.4 ended during stages IV-V. These strains are defective in synthesis of the spore cortex, which normally occurs during stage IV, so that the temperature-sensitive periods of these strains coincide with the times at which their phenotypic defects become apparent. Unexpectedly, the temperature-sensitive period of strain 181.3 was found to be longer than those of the other spoIVF strains (Fig. 3), and this strain formed significantly fewer heat-resistant spores at both the restrictive and the permissive temperatures (Table 3). These characteristics are presumably related to each other. There is no obvious reason for the low frequency of sporulation and the long temperature-sensitive period of strain 181.3, relative to the parental strain 181. Five other $\mathrm{Spo}^{-} \mathrm{Lys}^{-}$isolates obtained following transformation of strain MB68 by DNA prepared from strain 181 all formed heatresistant spores with the same frequency as strain 181.3 (results not shown). We have no explanation for the fact that different strains having the same mutation (spo-181) gave different results.

The possible effects on the gene products of mutations causing temperature sensitivity, and the relationship of temperature-sensitive periods to the times of gene-expression, are thoroughly discussed by Young (1976). The temperature-sensitive periods of strains carrying mutations in the $s p o O B$ locus are at the very beginning of sporulation, whereas those of strains carrying mutations in the spoIVF locus do not begin until stage IV. The clearly different temperaturesensitive periods show that their protein products function at well-separated stages of sporulation. The fact that the $s p o O B$ and spoIVF loci are adjacent on the chromosome might have indicated that they were different genes in a single polycistronic operon which was expressed during vegetative growth and the early stages of sporulation, and that the spoIVF gene-product did not intervene in sporulation until stage IV. This explanation could only be correct if the spoIVF587 and spoIVF 181 gene-products were able to rapidly re-assume an active conformation after heat-inactivation. If this were not so - and it is very unlikely - the temperature-sensitive periods of the spoIVF strains would have been seen to occur during the early stages of sporulation. The alternative explanation, which is much the more likely, is that genes in the spoOB and spoIVF loci are not parts of a single polycistronic operon and that they are expressed separately during sporulation. Further work, involving cloning of the genes in these loci and the study of their expression during sporulation, would be required to distinguish between these possibilities.

I.L.L. was in receipt of a SERC postgraduate studentship during the course of this work.

\section{REFERENCES}

Brehm, S. P., Le Hegarat, F. \& Hoch, J. A. (1975). Deoxyribonucleic acid-binding proteins in vegetative Bacillus subtilis: alterations caused by stage 0 sporulation mutations. Journal of Bacteriology 124, 977-984.

Carlton, B. C. (1966). Fine-structure mapping by transformation in the tryptophan region of Bacillus subtilis. Journal of Bacteriology 91, 1795-1803.
Coote, J. G. (1972a). Sporulation in Bacillus subtilis. Characterization of oligosporogenous mutants and comparison of their phenotypes with those of asporogenous mutants. Journal of General Microbiology 71, 1-15.

COOTE, J. G. (1972b). Sporulation in Bacillus subtilis. Genetic analysis of oligosporogenous mutants. Journal of General Microbiology 71, 17-27. 
Dunn, G., Torgersen, D. M. \& Mandelstam, J. (1976). Order of expression of genes affecting septum location during sporulation of Bacillus subtilis. Journal of Bacteriology 125, 776-799.

ERrington, J. \& MANDELSTAM, J. (1983). Variety of sporulation phenotypes resulting from mutations in a single regulatory locus, spoIIA, in Bacillus subtilis. Journal of General Microbiology 129, 2091-2101.

Esposito, M. S., Esposito, R. E., Arnaud, M. \& Halvorson, H. O. (1970). Conditional mutants of meiosis in yeast. Journal of Bacteriology 104, 202210.

Ferrari, F. A., Lang, D., Ferrari, E. \& Hoch, J. A. (1982). Molecular cloning of the $S p o O B$ sporulation locus in bacteriophage lambda. Journal of Bacteriology 152, 809-814.

GlenN, A. R. \& Mandelstam, J. (1971). Sporulation in Bacillus subtilis 168. Comparison of alkaline phosphatase from sporulating and vegetative cells. Biochemical Journal 123, 129-138.

Hirochika, H., Kobayashi, Y., Kawamura, F. \& SAITO, H. (1981). Cloning of sporulation gene spoOB of Bacillus subtilis and its genetic and biochemical analysis. Journal of Bacteriology 146, 494-505.

Hосн, J. A. \& Mathews, J. L. (1973). Chromosomal location of pleiotropic negative sporulation mutations in Bacillus subtilis. Genetics 73, 215-228.
Hoch, J. A., Shiflett, M. A., Trowsdale, J. \& Chen, S. M. H. (1978). Stage 0 genes and their products. In Spores VII, pp. 127-130. Edited by G. Chambliss \& J. C. Vary. Washington, D.C.: American Society for Microbiology.

Hranueli, D., Piggot, P. J. \& Mandelstam, J. (1974). Statistical estimate of the total number of operons specific for Bacillus subtilis sporulation. Journal of Bacteriology 119, 684-690.

LAMONT, I. L. \& MANDELSTAM, J. (1984). Identification of a new sporulation locus. spoIIIF, in Bacillus subtilis. Journal of General Microbiology 130, 12531261.

MARMUR, J. (1961). A procedure for the isolation of deoxyribonucleic acid from micro-organisms. Journal of Molecular Biology 3, 208-218.

Piggot, P. J. \& COOTE, J. G. (1976). Genetic aspects of bacterial endospore formation. Bacteriological Reviews 40, 908-962.

WARD, J. B., JR \& ZaHLER, S. A. (1973). Genetic studies of leucine biosynthesis in Bacillus subtilis. Journal of Bacteriology 116, 719-726.

YounG, M. (1976). Use of temperature-sensitive mutants to study gene expression during sporulation in Bacillus subtilis. Journal of Bacteriology 126, $928-$ 936. 